\title{
Screening av diabetespasienter er til liten nytte
}

\section{Screening for koronarsykdom hos hjertefriske diabetespasienter gir ikke lavere mortalitet.}

Koronarsykdom er en vanlig årsak til kardiovaskulær død hos pasienter med diabetes type 1 og type 2. Amerikanske forskere under-

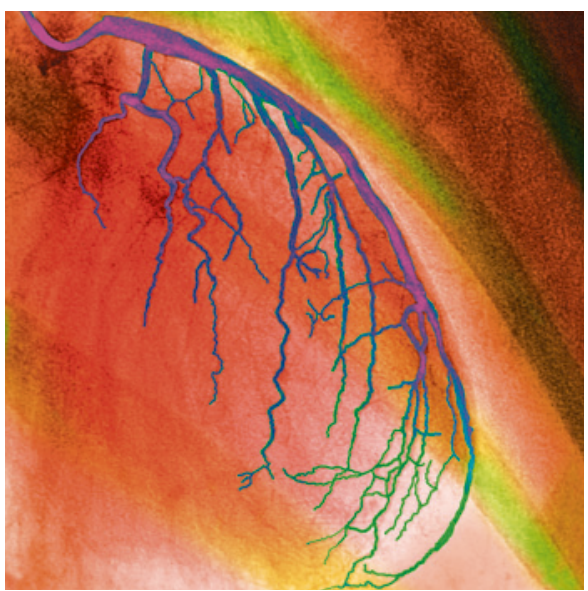

Illustrasjonsfoto: Science Photo Library søkte om screening for koronarsykdom ved bruk av koronar angiografi med CT ga lavere mortalitet og mindre koronar sykelighet (1). Rundt halvparten av 900 diabetespasienter uten kjente symptomer på koronarsykdom ble randomisert til CT-undersøkelse. Det var ingen statistisk signifikante forskjeller i mortalitet $(3,5 \%$ versus $4,3 \%$, hasardratio (HR) $=0,82(95 \%$ KI $0,42-1,60)$, forekomst av ikke-dødelig hjerteinfarkt $(1,5 \%$ versus $1,8 \%, \mathrm{HR}=0,83(95 \% \mathrm{KI} 0,30-2,28)$ eller ustabil angina med sykehusinnleggelse $(2,0 \%$ versus $2,0 \%, \mathrm{HR}=0,94(95 \% \mathrm{KI}$ 0,37-2,38) mellom intervensjonsgruppen og kontrollgruppen, som ble fulgt i i gjennomsnitt fire år (SD 1,7).

- Denne studien er klinisk viktig, fordi det er høy forekomst av asymptomatisk koronarsykdom hos diabetespasienter, sier Tor Ole Klemsdal, seksjonsleder ved Preventiv kardiologi, Avdeling for endokrinologi, sykelig overvekt og forebyggende medisin ved Medisinsk klinikk, Oslo universitetssykehus. - Det er da nærliggende å anta at screening ville kunne identifisere dem som bør ha mer aggressiv behandling, både medikamentelt og eventuelt med revaskularisering, sier han.

- Resultatene tyder imidlertid på minimal gevinst ved en slik strategi, trolig fordi god medisinsk forebyggende behandling er det viktigste og skal gis uansett screeningresultat, fortsetter Klemsdal.

- Det ble observerte langt færre kardiovaskulære hendelser enn forutsatt, slik at studiens styrke til å påvise gevinst av screeningen ble liten. Man kan også stille spørsmål ved en del av behandlingsmålene man valgte for den aggressive behandlingen $\left(\mathrm{HbA}_{1 \mathrm{C}}\right.$-mål $<6,0 \%$, HDL-nivå $>50 \mathrm{mg} /$ $100 \mathrm{ml}(1,3 \mathrm{mmol} / \mathrm{l})$ og systolisk blodtrykk $<120 \mathrm{~mm} \mathrm{Hg}$ ), ettersom det er liten dokumentasjon for disse målene, sier Klemsdal.

\section{Tor Atle Rosness}

Tidsskriftet

\section{Litteratur}

1. Muhlestein JB, Lappé DL, Lima JA et al. Effect of screening for coronary artery disease using CT angiography on mortality and cardiac events in high-risk patients with diabetes: the FACTOR-64 randomized clinical trial. JAMA 2014: 312: $2234-43$.

\section{Trening kan svekke hjertefunksjonen ved kardiomyopati}

\author{
Høyintensiv trening kan svekke hjertefunksjonen til pasienter med \\ arytmogen høyre ventrikkel-kardiomyopati og hos genbærende familie- \\ medlemmer som ikke har utviklet sykdom.
}

Arytmogen høyre ventrikkel-kardiomyopati (ARVC) er en arvelig form for kardiomyopati, der hjertemuskelceller nekrotiserer og gradvis blir erstattet med fett- og bindevev. Denne prosessen disponerer for ventrikulære arytmier. Trening gir økt risiko for arytmier, og sykdommen er forbundet med idrettsdød og plutselige dødsfall hos unge mennesker.

I en studie som nylig er publisert i European Journal of Heart Failure, har man undersøkt hvordan høyintensiv fysisk aktivitet påvirker myokardfunksjonen til pasienter med denne formen for kardiomyopati og deres friske familiemedlemmer med den samme sykdomsmutasjonen (1). I alt 110 personer, 65 med sykdom og 45 mutasjonspositive familiemedlemmer, ble undersøkt. Høyintensiv trening ble definert som $\geq 4$ timer hard fysisk aktivitet per uke i minst seks år. Alle pasientene og familiemedlemmene ble undersøkt med ekkokardiografi og MR av hjertet. De som drev høyintensiv trening, hadde redusert biventrikulær funksjon sammenliknet med de andre - dette gjaldt både dem med arytmogen høyre ventrikkelkardiomyopati og mutasjonspositive fami- liemedlemmer. Treningsintensitet og treningsmengde var assosiert med nedsatt funksjon av høyre og venstre ventrikkel.

- Denne studien gir verdifull informasjon og støtter anbefalingen om at høyintensiv trening skal frarådes til pasienter med arytmogen høyre ventrikkel-kardiomyopati, sier Jan Pål Loennechen, som er overlege og førsteamanuensis ved St. Olavs hospital. - Hvilke råd man skal gi til mutasjonspositive slektninger uten tegn til sykdom er mer usikkert. Mye tyder på at også disse bør unngå høyintensive treningsformer. Det er viktig å påvise arytmogen høyre ventrikkel-kardiomyopati så tidlig som mulig for å unngå sykdomsprogrediering og plutselig død, og for å kunne finne et fornuftig treningsnivå for pasienten, sier Loennechen.

\section{Lise Mørkved Helsingen}

Tidsskriftet

\section{Litteratur}

1. Saberniak J, Hasselberg NE, Borgquist R et al. Vigorous physical activity impairs myocardial function in patients with arrhythmogenic right ventricular cardiomyopathy and in mutation positive family members. Eur J Heart Fail 2014; 16: 1337-44.

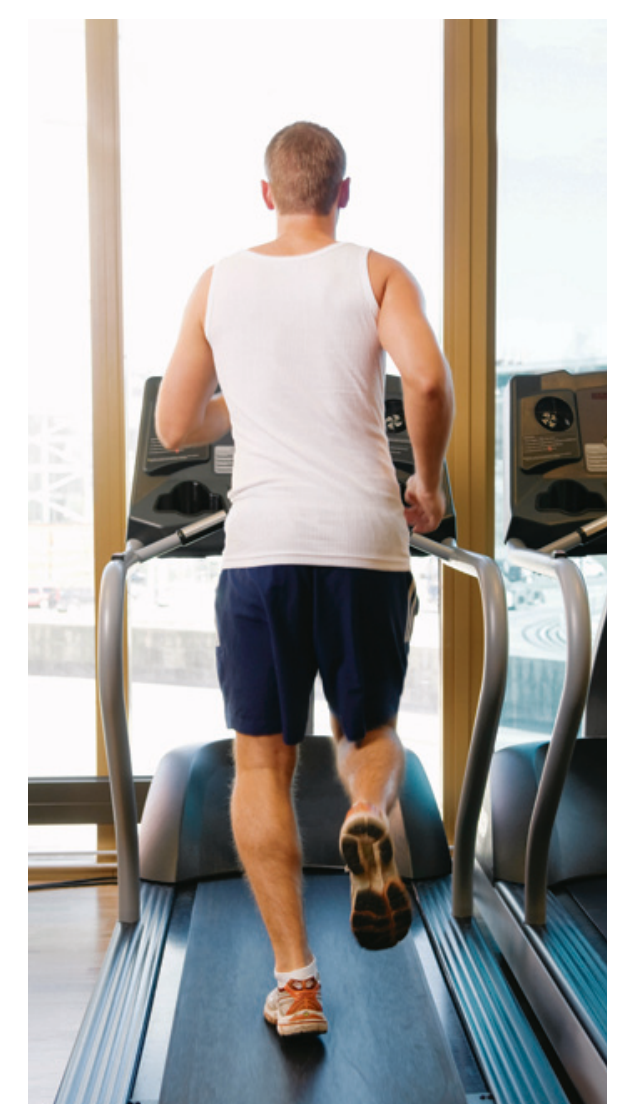

Illustrasjonsfoto: Maskot/NTB scanpix 